\title{
The Role of Collaborative Learning Based STSE in Acid Base Chemistry: Effects on Students' Motivation
}

\author{
Erfan Priyambodo ${ }^{1, *}$ Nur Fitriyana ${ }^{1}$, Metridewi Primastuti $^{1}$, and Farizky \\ Aquarisco Duo Artistic ${ }^{2}$ \\ ${ }^{1}$ Chemistry Education Department, Faculty of Mathematics and Natural Sciences, Universitas Negeri \\ Yogyakarta, Indonesia \\ ${ }^{2}$ Student of Bachelor of Education in Chemistry Study Programme, Faculty of Mathematics and Natural \\ Sciences, Universitas Negeri Yogyakarta, Indonesia \\ *Corresponding author. Email: erfan@uny.ac.id
}

\begin{abstract}
Designing learning environment that leads on the improvement of students' motivation becomes crucial for chemistry teachers. The objective of this research was to investigate the effects of collaborative learning-based Science, Technology, Society, and Environment (STSE) towards students' motivation in acid base chemistry lesson. A pre-test post-test non-equivalent control group design was adopted in this quasi-experimental research. Two classes who enrolled in science programme from a public senior high school in Sleman Regency, Yogyakarta, Indonesia were used as the research sample of this study. Through cluster random sampling, one group was devoted as experimental class $(\mathrm{N}=30)$ receiving collaborative learning based STSE while the other one as control class $(\mathrm{N}=32)$ taught by traditional teaching. A Chemistry Motivation Scale (CMS) was administered as data collection tool of students' motivation before and after the teaching intervention. These data were analysed using descriptive statistics, Mann Whitney U, Kruskal Wallis, and Wilcoxon tests. The findings of this research revealed that there was significantly difference of students' motivation among experimental and control classes. This difference was occurred in favour of experimental class. Moreover, the data of students' motivation on experimental class signified a higher improvement than the control class. Thus, it can be highlighted that collaborative learning based STSE has an effect in improving students' motivation. The result of this study recommends to implement collaborative learning based STSE since it is promising in order to promote students' motivation in learning chemistry.
\end{abstract}

Keywords: acid base, collaborative learning, STSE, motivation.

\section{INTRODUCTION}

Making learning environment interesting for students become the challenge for teacher in all level of educational field. As all of the teacher, chemistry teacher had main role in conducting teaching learning instruction that brings on improvement of students' motivation in studying chemistry [1]. Since varied studies revealed that student had a lacked of students' interest, attitude, and motivation toward chemistry [23]; another study proven that it is because the meaningless of chemistry content [4-5]. Students considered chemistry as meaningless due to their inability in using chemistry content knowledge in overcoming real world problems. Further, they suggest that chemistry materials are not useable in their daily life [6-7]. Thus, the students pretend in studying chemistry including acid base chemistry. They found difficulties in making calculation of quantitative knowledge [8-9]; they regard acid base concepts are abstract [8, 10]; and the necessary of reasoning skill to understand the concept $[9,11]$. Such the abstractness concept of acid base chemistry, students found difficulties in relating acid base chemistry knowledge and use it in everyday life. Thus, it implied on the decline of students' motivation and intention to learn acid base chemistry. 
When the students had willingness in studying chemistry, they will gain what they deserved. This intention to learn chemistry that called as chemistry learning motivation. This motivation determines students' success and effectiveness in studying chemistry [12]. Motivation defined as someone strength that could arise individuals' intention in performing certain activity. If the source of intention comes from its individuals, it called intrinsic motivation. Whereas, if the source of intention comes from outside individuals, its known as extrinsic motivation. The higher students' motivation, the better students' attitude in the context of teaching learning instruction. As study performed by Suyanto, Wantini, Baidi and Amurdawati [13] recommends that students' motivation improves their desire to accomplish individual targets. This students' motivation influenced by their attention, relevance, and satisfaction [14]. Therefore, it is necessary to build students' motivation in order to attain a better students' learning outcomes [12, 15]. To deal with this issue, an appropriate learning strategy is required to promote students' motivation in learning acid base chemistry materials. The teacher needs to use their creativity to design chemistry learning environment that will attract students' interest and increase students' motivation. Thus, it will signify on the development of students' ability in relating chemistry concept with rapidly changing of societies.

Recent studies had been experienced various learning strategies in order to elicit students' motivation in learning chemistry. Augustinovič [16] suggest to implement interesting teaching methods using an embedded technology to construct students' engagement in teaching learning instruction. The role of technology had been implemented through the use of virtual laboratory [17]; flipped approach with peerled team learning [15]; and computer-assisted instruction [18]. In addition, students' motivation had been developed through various pedagogies focused on student centred learning paradigm such as contextbased learning [19-20]; socio-scientific issues from societal view [21]; guided inquiry learning with socio-scientific issues context [22]; 5E learning cycle [23]; case-based instruction [24-25] and inquirybased teaching [26]. In another perspective, the interaction among students brings significant effects on students' motivation i.e., cooperative learning instruction for conceptual change [27] and cooperative integrated process inquiry [28]. As a conclusion the prominent opportunity to increase students' motivation is by providing students' engagement in learning activities through student centred learning [29]. Moreover, the increase of students' interaction in teaching learning instruction could become another alternative way to foster students' motivation. One of teaching pedagogy that facilitate students' engagement in active learning is through STSE approach. However, the use of STSE in chemistry learning still rarely performed [30-31].

The STSE approach present the linking of chemistry content knowledge with everyday life issues [31-32]. This STSE enables the students to make relationship among science, technology, society, and environment in authentic inquiry activities that necessary in solving daily life issues [33]. Since STSE integrates student centred learning paradigm, thus the students were actively participated in finding the new knowledge. The constructed knowledge they found could be extended in order to solve real world issues. Thus, the students are more aware with the problems close to their life. They understand the use of content knowledge in the everyday lives that could bring on their willingness in studying chemistry, hence it will boost students' motivation and interest in learning chemistry [34]. Moreover, the STSE makes students' engagement in teaching instruction enhanced, thus it allows the interaction among students in the class. This interaction could be facilitated using collaborative learning method that enables students to work in heterogeneous small group. The collaborative learning increases meaningful relationship among students in small groups in practicing and experiencing teaching learning [28]. The role of the teacher in this occasion act as facilitator [35]. This interaction improves students' motivation in facing real world problems.

As aforementioned discussion, this study offers on the implementation of collaborative learning based STSE. The collaborative learning based STSE integrates student centred learning theory. Thus, the STSE facilitating students in understanding acid base chemistry concepts that used in solving cases of everyday lives by their own. While in the collaborative learning, students perceived interaction among students, teaching materials, and the teacher. These kinds of interaction bring significant opportunity for students in finding acid base chemistry concept in meaningful way. Therefore, the combination of STSE with collaborative learning becomes interesting choice to increase students' motivation in learning acid base chemistry. The following research questions underlying the present study:

a. Is there any significant effect of the teaching intervention on students' motivation mean score between experimental and control class?

b. Is there any significant enhancement on students' motivation before and after the implementation of collaborative learning based STSE? 


\section{METHODS}

The research methods conducted in this study explained in this section.

\subsection{The Research Design}

A pre-test post-test non-equivalent control group design was adopted in this quasi experimental research. Through this design, the study was investigated the effects of one or more experimental group which were given certain intervention with one comparison group that wasn't received treatment towards certain dependent variable [36]. Therefore, there were two different groups in this research, one group was devoted as experimental class receiving collaborative learning based STSE while the other one as control class taught by traditional teaching. The dependent variable measured in this research was students' motivation in studying acid base chemistry before and after the teaching intervention. The research design adopted in this research briefly presented in Table 1.

\subsection{The Research Sample}

As many as 62 eleventh grader who enrolled in science program from a public senior high school in Sleman Regency, Yogyakarta, Indonesia was used as the research sample of this study. These number of students were comprised from two classes; one group was devoted as experimental class and the other one as control class. A total of 30 students on experimental class (consisted of 14 boys and 16 girls) receiving collaborative learning based STSE and 32 students on control class (consisted of 16 boys and 16 girls) taught by traditional teaching.

The sample in this research came from similar economic background, have approximately aged 1516 years old, no difference in term of students' prior knowledge in chemistry, and chosen by cluster random sampling since it assigned by selecting the groups rather than individuals [37]. The two classes in this research were followed all of research procedures, began by pre-test, teaching intervention, until the post-test.

\subsection{The Research Procedure}

This research was held in acid base chemistry lesson of eleventh senior high school grader of 2019/ 2020 academic year. The teaching learning instruction on acid base chemistry lesson was performed for 5 sessions on both classes. Further, the two classes were taught by the same chemistry teacher. The research procedures initiate by administered paper and pencil pre-test in the term of students' motivation, followed by giving teaching intervention, and closing by giving students' motivation post-test. The teaching intervention on both classes used student centred learning paradigm and they work in a collaborative group with each group consist of 3-4 students. Therefore, the students allow to construct their own knowledge through their selves and their peers in group discussion.

The experimental class taught by collaborative learning based STSE that have main characteristics learning phase of invitation, exploration, solution, application, and strengthen concept. The teaching learning activities in this group was initiating by presenting daily life phenomenon and the students need to correlate its relationship with the aspect of Science, Technology, Society, and Environment. Whereas on the control class was implemented scientific approach, a usual teaching learning instruction suggested by Indonesian curriculum. This scientific approach consists of observing, proposing question, collecting data, associating, and communicating activities. The brief different of teaching intervention on both classes shown in Table 2 .

Table 1. A pre-test post-test non-equivalent control group design

\begin{tabular}{|l|l|l|l|}
\hline Class & Pre-test & Experimental Treatment & Post-test \\
\hline Experimental & CMS & Collaborative learning based STSE & CMS \\
\hline Control & CMS & Traditional teaching & CMS \\
\hline \multicolumn{2}{|l}{ Description: CMS = Chemistry Motivation Scale } \\
\hline
\end{tabular}

Table 2. The instruction process on experimental and control class

\begin{tabular}{|c|c|c|}
\hline Activity & Experimental & Control \\
\hline Pre-test & $\begin{array}{l}\text { Before the implementation of collaborative } \\
\text { learning based STSE, the CMS was administered } \\
\text { through paper and pencil test. The students } \\
\text { accomplished the CMS for } 30 \text { minutes. }\end{array}$ & $\begin{array}{l}\text { As the experimental group, students } \\
\text { on control group dealing with CMS for } 30 \\
\text { minutes before the acid base chemistry } \\
\text { teaching. }\end{array}$ \\
\hline
\end{tabular}




\begin{tabular}{|c|c|c|}
\hline Treatment & 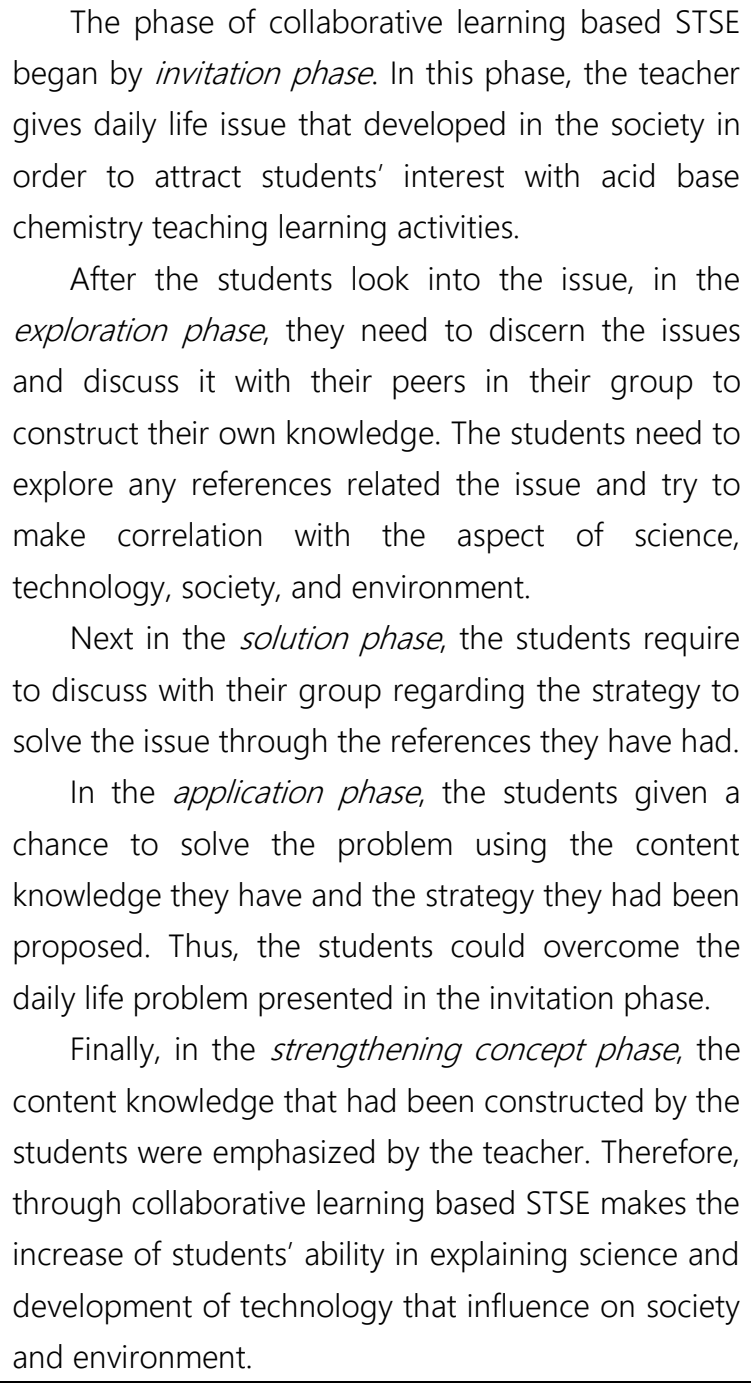 & $\begin{array}{l}\text { The scientific approach initiates by } \\
\text { observing phase that asking the students } \\
\text { to observe certain teaching materials. } \\
\text { Next, in the proposing question } \\
\text { phase, the students need make several } \\
\text { questions about the teaching material as } \\
\text { much as possible. These questions would } \\
\text { be managed by the teacher to guide the } \\
\text { teaching learning instruction. } \\
\text { After that, in the collecting } \\
\text { information phase, the students explore } \\
\text { any information from reliable resources to } \\
\text { answer the questions they had been } \\
\text { proposed. } \\
\text { Further, in the associating phase, the } \\
\text { students could solve any problems related } \\
\text { the content knowledge they learned. They } \\
\text { discuss the problems with their peers in } \\
\text { their group. } \\
\text { Finally, in the communicating phase, } \\
\text { the students ask to present their ideas } \\
\text { related the content knowledge they } \\
\text { constructed. } \\
\text { emphasize and add any additional } \\
\text { information that may had not mention by } \\
\text { the students. }\end{array}$ \\
\hline Post-test & $\begin{array}{l}\text { The CMS was reused to collect the data of } \\
\text { students' motivation on experimental class after the } \\
\text { collaborative learning based STSE had been finished } \\
\text { to be implemented. }\end{array}$ & $\begin{array}{l}\text { In order to collect the post-test data } \\
\text { of students' motivation after the } \\
\text { traditional teaching on acid base } \\
\text { chemistry, the CMS was administered on } \\
\text { the control class. }\end{array}$ \\
\hline
\end{tabular}

\subsection{The Research Instrument}

This research was collected the data of students' motivation in learning acid base chemistry before and after the experimental manipulation. To obtain these data, a Chemistry Motivation Scale (CMS) was administered as a data collection tool. The CMS is a questionnaire and belongs to non-test instrument which employs five points of Likert scale varied from strongly disagree until strongly agree. This CMS consisted of 40 items of statement that well distributed into positive and negative item. The scoring guide for positive item of CMS use following rule: the response for strongly agree signified 5 points; agree implied 4 points; doubt indicated 3 points; disagree signified 2 points; and strongly disagree implied 1 point. While, for the negative item using the contrast rule from the response for strongly agree signified 1 point until strongly disagree indicated 5 points. In addition, the CMS integrated several indicators of students' motivation with its distribution presented in Table 3 .

The CMS use in this research was adapted from Vitrianingsih [38] with some necessary substantial changes. Thus, this CMS needs to be validated and it was performed through content and empirical validation. The CMS content validation began by asking the judgment from experts in chemistry education field. The experts checked the suitability of the indicators with each item, the correct Indonesian grammatical, and the motivation content knowledge. 
The feedbacks from the experts were considered and important revision were made to improve the quality of CMS. After that, the revised version of CMS was administered towards a group of eleventh grader out of the sample of the research. The responses from the

Table 3. Indicators distribution on CMS

\begin{tabular}{|c|c|c|c|c|}
\hline \multirow[t]{2}{*}{ Sub Dimension } & \multirow[t]{2}{*}{ Indicators } & \multicolumn{2}{|c|}{ Number of Item } & \multirow{2}{*}{$\begin{array}{l}\text { Total } \\
\text { items }\end{array}$} \\
\hline & & Positive & Negative & \\
\hline \multirow[t]{2}{*}{ Efficacy } & $\begin{array}{l}\text { Persevering in facing the acid base chemistry } \\
\text { assignment }\end{array}$ & 3 & 2 & 5 \\
\hline & Tenacious in facing acid base chemistry difficulties & 3 & 2 & 5 \\
\hline \multirow[t]{2}{*}{ Eagerness } & Interested in studying acid base chemistry & 3 & 2 & 5 \\
\hline & $\begin{array}{l}\text { Having a high enthusiasm in solving acid base } \\
\text { chemistry related daily life problems }\end{array}$ & 4 & 1 & 5 \\
\hline \multirow[t]{2}{*}{ Performance } & Able to work independently or in a group & 4 & 1 & 5 \\
\hline & $\begin{array}{l}\text { Willingness in finishing regular task of acid base } \\
\text { chemistry }\end{array}$ & 3 & 2 & 5 \\
\hline \multirow[t]{3}{*}{ Curiosity } & Able to defend argument(s) & 3 & 2 & 5 \\
\hline & Showing scepticism in arguing new knowledge(s) & 3 & 2 & 5 \\
\hline & Total number of items & 26 & 14 & 40 \\
\hline
\end{tabular}

students were analysed in order to examine the empirical validity and reliability of the item. The result of the analysis presents that a total of 40 items were valid and found to be highly reliable since the Cronbach Alpha value signified 0.941 [39-40]. Thus, the CMS is a valid and reliable instrument to collect the data of students' motivation in this research.

\subsection{Data Analysis}

The data of students' motivation before and after the teaching intervention in this research were analyzed using several procedures consisting descriptive statistics, Mann Whitney U, Kruskal Wallis, and Wilcoxon tests. The descriptive statistics was used to present the tendency central on students' motivation among experimental and control classes. In order to examine the significantly difference explaining the condition of students' motivation before and after the teaching intervention, Mann Whitney $U$ test was employed in the analysis. Moreover, Kruskal Wallis test was utilized to determine the effects of teaching intervention on overall students' motivation with each dimension of motivation. The last, Wilcoxon test were performed to examine the improvement of students' motivation score before and after the collaborative learning based STSE had been implemented.

\section{RESULTS AND DISCUSSION}

The finding with its explanation and discussion concerning the result of this study presented in this section. The first is the result of descriptive statistics data on both, experimental and control classes covering the mean score, standard deviation, number of students, the highest, and the lowest score before and after the teaching intervention. The descriptive statistics on students' motivation among experimental and control classes present on Table 4. Examining the data on Table 4, it is implied that after the research treatment had been applied, students' motivation on experimental class signified a better score than the control class. Before the treatment, students on experimental class achieve pre-test score of 69.07. A slight difference on control class that achieve a higher pre-test score on students' motivation of 69.36. As a contrast, after the treatment, the experimental group had a higher mean score on students' motivation $(\mathrm{M}=71.25)$ than the control group $(\mathrm{M}=68.87)$. Thus, the students' motivation on control class were decline after the treatment. Further, the data of students' motivation before and after the teaching intervention were analyse using Mann Whitney $U$ test. This analysis aims to check the mean score differences of pre-test and post-test on the two classes. The result of this analysis shown in Table 5. 
Table 4. The descriptive statistics of the research on students' motivation

\begin{tabular}{|l|l|l|l|l|}
\hline \multirow{2}{*}{ Parameter } & \multicolumn{2}{|c|}{ Experimental } & \multicolumn{2}{c|}{ Control } \\
\cline { 2 - 5 } & Pre-test & Post-test & Pre-test & 68.87 \\
\hline Mean score & 69.07 & 71.25 & 69.36 & 5.91 \\
\hline SD & 4.10 & 4.81 & 5.24 & 88.00 \\
\hline Highest Score & 77.50 & 80.00 & 79.00 & 59.00 \\
\hline Ideal Score & 61.00 & 63.00 & 100 & 100 \\
\hline Number of Students & 100 & 100 & 32 & 32 \\
\hline
\end{tabular}

Table 5 explains that before the teaching intervention, students' motivation among experimental and control classes shown no statistically significant difference. It means that before the treatment, students had similar motivation in learning acid base chemistry materials. Moreover, when the post-test data of students' motivation were examined, it found statistically significant difference among experimental and control groups in favour of experimental group. Thus, the intervention on experimental group that is collaborative learning based STSE contributes in improving students' motivation in learning acid base chemistry. Therefore, to examine the effects of this teaching intervention among experimental and control groups, Kruskal Wallis test was performed. See Table 6 to determine the effects of teaching intervention on students' motivation with each dimension of motivation

Based on the result of Kruskal Wallis test on Table 6, it is clearly depicted that collaborative learning based STSE had a significant effect on overall students' motivation, the dimension of students' motivation of efficacy, and eagerness. However, on the dimension of performance and curiosity of students' motivation signified no differences. Thus, collaborative learning based STSE had a significant influence on students' motivation especially on efficacy and eagerness dimensions. It explains that collaborative learning based STSE brings contribution a total of $16.9 \%$ in improving students' motivation with the dimension of efficacy signified $13.8 \%$ and eagerness of $9.1 \%$.

The implementation of collaborative learning based STSE in this research boost students' motivation in learning acid base chemistry. The STSE allows the students to construct acid base chemistry content knowledge and linking it with daily life phenomena [31-32]. Realizing that acid base chemistry related with everyday problems, thus it attracts students' interest and intention in learning the materials. The STSE instruction provides an elaborated and deeper conceptual understanding. Therefore, it engages the role of students in learning activities that signified in affecting their motivation through the relevance of school chemistry to daily lives [23]. Given a related study arguing that higher students who are not motivated caused by the irrelevance of the course content [41], by implementing STSE in the acid base chemistry learning it provides the relevance of the content with students' life. Therefore, the research treatment on experimental class significantly influences students' motivation in studying acid base chemistry.

Phrased differently, in the chemistry learning, it is important to consider motivation because their success in chemistry is inherently tied to motivational and other affective processes [12].

Table 5. Mann Whitney U on pre-test and post-test mean score of experimental and control group

\begin{tabular}{|l|l|l|l|l|l|l|l|}
\hline Test & Class & N & $\begin{array}{l}\text { Mean } \\
\text { Rank }\end{array}$ & $\begin{array}{l}\text { Sum of } \\
\text { Ranks }\end{array}$ & S & (onclusion*) \\
\hline \multirow{2}{*}{ Pre-test } & Experimental & 30 & 30.02 & 900.50 & 435.500 & 0.530 & No difference \\
\cline { 2 - 5 } & Control & 32 & 32.89 & 1052.50 & & \\
\cline { 1 - 5 } Post-test & Experimental & 30 & 36.55 & 1096.50 & 328.500 & 0.033 & Significantly difference \\
\cline { 2 - 5 } & Control & 32 & 26.77 & 856.50 & & \\
\hline
\end{tabular}

*) Confidence level of $95 \%$ 
Table 6. Kruskal Wallis test on students' motivation among experimental and control class

\begin{tabular}{|c|c|c|c|c|c|c|c|}
\hline Parameter & Group & $\begin{array}{l}\text { Mean } \\
\text { Rank }\end{array}$ & $d f$ & $\begin{array}{l}\text { Chi } \\
\text { Square }\end{array}$ & $P$ & Conclusion*) & $\begin{array}{l}\text { Partial Eta } \\
\text { Squared }\end{array}$ \\
\hline \multirow{2}{*}{$\begin{array}{l}\text { Overall } \\
\text { Students' } \\
\text { Motivation }\end{array}$} & Experimental & 39.73 & \multirow[t]{2}{*}{1} & \multirow[t]{2}{*}{12.126} & \multirow[t]{2}{*}{0.000} & \multirow{2}{*}{$\begin{array}{l}\text { Significantly } \\
\text { difference }\end{array}$} & \multirow[t]{2}{*}{0.169} \\
\hline & Control & 23.78 & & & & & \\
\hline \multirow[t]{2}{*}{ Efficacy } & Experimental & 38.90 & \multirow[t]{2}{*}{1} & \multirow[t]{2}{*}{9.842} & \multirow[t]{2}{*}{0.002} & \multirow{2}{*}{$\begin{array}{l}\text { Significantly } \\
\text { difference }\end{array}$} & \multirow[t]{2}{*}{0.138} \\
\hline & Control & 24.56 & & & & & \\
\hline \multirow[t]{2}{*}{ Eagerness } & Experimental & 36.67 & \multirow[t]{2}{*}{1} & \multirow[t]{2}{*}{4.787} & \multirow[t]{2}{*}{0.029} & \multirow{2}{*}{$\begin{array}{l}\text { Significantly } \\
\text { difference }\end{array}$} & \multirow[t]{2}{*}{0.091} \\
\hline & Control & 26.66 & & & & & \\
\hline \multirow[t]{2}{*}{ Performance } & Experimental & 35.30 & \multirow[t]{2}{*}{1} & \multirow[t]{2}{*}{2.600} & \multirow[t]{2}{*}{0.107} & \multirow[t]{2}{*}{ No Difference } & \multirow[t]{2}{*}{0.052} \\
\hline & Control & 27.94 & & & & & \\
\hline \multirow[t]{2}{*}{ Curiosity } & Experimental & 35.57 & \multirow[t]{2}{*}{1} & \multirow[t]{2}{*}{2.982} & \multirow[t]{2}{*}{0.084} & \multirow[t]{2}{*}{ No Difference } & \multirow[t]{2}{*}{0.051} \\
\hline & Control & 27.69 & & & & & \\
\hline
\end{tabular}

*) Confidence level of $95 \%$

Table 7. Wilcoxon test results on experimental class

\begin{tabular}{|c|c|c|c|c|c|}
\hline Parameter & $N$ & Mean Rank & Sum of Ranks & Sig & Conclusion*) \\
\hline \multicolumn{6}{|c|}{ Overall Students' Motivation } \\
\hline Pre-test & 30 & 11.17 & 33.50 & \multirow[t]{2}{*}{0.000} & \multirow[t]{2}{*}{ Significantly difference } \\
\hline Post-test & 30 & 13.80 & 317.50 & & \\
\hline \multicolumn{6}{|l|}{ Efficacy } \\
\hline Pre-test & 30 & 11.00 & 33.00 & \multirow[t]{2}{*}{0.000} & \multirow[t]{2}{*}{ Significantly difference } \\
\hline Post-test & 30 & 13.27 & 292.00 & & \\
\hline \multicolumn{6}{|l|}{ Eagerness } \\
\hline Pre-test & 30 & 13.75 & 55.00 & \multirow[t]{2}{*}{0.003} & \multirow[t]{2}{*}{ Significantly difference } \\
\hline Post-test & 30 & 12.86 & 270.00 & & \\
\hline \multicolumn{6}{|l|}{ Performance } \\
\hline Pre-test & 30 & 13.21 & 92.50 & \multirow[t]{2}{*}{0.097} & \multirow[t]{2}{*}{ No Difference } \\
\hline Post-test & 30 & 12.21 & 207.50 & & \\
\hline \multicolumn{6}{|l|}{ Curiosity } \\
\hline Pre-test & 30 & 8.78 & 79.00 & \multirow[t]{2}{*}{0.200} & \multirow[t]{2}{*}{ No Difference } \\
\hline Post-test & 30 & 12.67 & 152.00 & & \\
\hline
\end{tabular}

*) Confidence level of $95 \%$

Facilitating direct interaction with peers, teaching materials, and the teacher were seen as key factors in improving students' pretention and motivation [29]. As the finding in this research, the interaction among the students on collaborative groups gives an influence on students' motivation. Using group collaboration, it brings students' willingness in performing all of teaching instruction. The collaborative learning increases meaningful relationship among students in small groups in practicing and experiencing teaching learning [28, 42]. Thus, the presence of well managed group discussion with their peers, boosts students' motivation in learning chemistry. Furthermore, to determine the improvement of overall students' motivation and each dimension of motivation before and after the students experienced collaborative learning based STSE, Wilcoxon test was executed (see Table 7).

Table 7 present the significant improvement of overall students' motivation with each dimension of motivation before and after collaborative learning based STSE had been treated. A statistically significant improvement found on the dimension of 
eagerness and efficacy also overall students' motivation. The other two dimensions of motivation which were performance and curiosity signified no enhancement. The linking between chemistry concept with real world issues could develop students' efficacy. As an active learning, the constructed concept helps the students retain their knowledge in long term memory [43]. Thus, they tend to try their best in solving acid base chemistry cases using content knowledge that had been constructed by their own. Therefore, the increase of students' engagement in learning activities, improve students believe on their ability to solve the issues [44].

Through the presence of STSE learning, students discern the use of acid base chemistry knowledge in the everyday lives. It activates students' willingness in studying chemistry and boost students' motivation especially their eagerness in learning chemistry [34]. As an example, when the students learn about the reaction among acid and base solution, the students were given a case about heartburn phenomenon. Since the heartburn phenomenon caused by an excessive of acid, thus it should be cured by inhaling antacid. The students learn how the reaction of an acid in the human stomach with the antacid. This example of related phenomenon enhances students' eagerness in learning acid base chemistry. The result of this research confirmed by previous study that believe demonstrating teaching materials increase students' motivation in the instruction [45]. Accordingly, the implementation of collaborative learning based STSE in this research facilitating students to improve students' motivation in learning acid base chemistry concept.

\section{CONCLUSION}

Facilitating learning environment for students that could increase students' engagement and motivation in the chemistry lesson become major emphasis for all of chemistry teacher. The enhancement of students' motivation in studying chemistry become important since it is contributing in defining students' learning outcomes. In the light of the finding of this research, it is revealed that collaborative learning based STSE gives significant effects on students' motivation in studying chemistry. An improvement of students' motivation before and after the implementation of collaborative learning based STSE signified that linking the chemistry concept with everyday life issues attract students' efficacy and eagerness in studying chemistry. They are realizing the important of learning chemistry and the use of chemistry concept in the real-world life. Therefore, applying collaborative learning based STSE should be considered since it provides chemistry in meaningful way that contributes in dealing and pursuing future career for the students.

Seeing the result of this research, the collaborative learning based STSE could be performed with the distinction of chemistry subject areas and the grade level with the extent of research samples. For future studies, it is suggested to use blended learning mode in delivering chemistry content knowledge using STSE approach because the presence of online learning in this mode gives significant effects on students' self-efficacy as the part of motivation expectancy value $[43,46]$ and students' self-regulated learning [47]. Moreover, the addition of computer assisted instruction could be employ because it enables in improving students' performance and motivation in the certain subject [18] such as through flipped class room [48]. Thus, the effectiveness of collaborative learning based STSE in comprehensive result will be reveal.

\section{AUTHORS' CONTRIBUTIONS}

This study was a part of undergraduate thesis project by the fourth author. The research activities of the fourth author was under the supervision of the first three authors.

\section{ACKNOWLEDGMENTS}

The authors showing their gratitude for Universitas Negeri Yogyakarta for funding this research through Excellent Higher Education Research Grant of 2020.

\section{REFERENCES}

[1] Fauziah, I. Safiah, \& S. Habibah, Upaya meningkatkan motivasi belajar siswa melalui lesson study di kelas V SD Negeri Lampagen Aceh Besar, Jurnal Ilmiah Pendidikan Guru Sekolah Dasar 2(1) (2017) 30-38.

[2] S. O. Adodo, \& L. O. Gbore, Prediction of attitude and interest of science students of different ability on their academic performance in basic science, International Journal of Psychology and Counselling 4(6) (2012) 68-72. DOI: http://dx.doi.org/10.5897/IJPC10.049

[3] J. Osborne, S. Simon, \& S. Collins, Attitudes towards science: A review of the literature and its implications, Int. J. Sci. Educ. 25(9) (2010) 1049-1079.

DOI: https://doi.org/10.1080/0950069032000032199

[4] D. Corrigan, \& P. Fensham, The roles of chemistry in vocational education Chemical Education: Towards Research-based Practice 
ed $\mathrm{J} \mathrm{K}$ Gilbert et al, Kluwer Academic Publishers., 2002

[5] A. Wiyarsi, H. Pratomo, \& E. Priyambodo, Chemistry learning: Perception and interest of vocational high school student of automotive engineering program, Proc. Int. Sem. on Sci. Educ. (Yogyakarta) vol 3, Yogyakarta, Graduate School of UNY, 2017, pp 359-366.

[6] J. Osborne, \& J. Dillon, Science education in Europe: Critical reflections, The Nuffield Foundation, 2008.

[7] A. Hofstein, I. Eilks, \& R. Bybee, Societal issues and their importance for contemporary science education: a pedagogical justification and the state of the art in Israel, Germany and the USA, International Journal of Science and Mathematics Education 9 (2011) 1459-1483. DOI: https://doi.org/10.1007/s10763-010-9273$\underline{9}$

[8] G. Sirhan, Learning difficulties in chemistry: An overview, Journal of Turkish Science Education, 4(4) (2007) 2-20. http://www.tused.org/index.php/tused/article/vie w/664.

[9] M. Woldeamanuel, H. Atagana, \& T. Engida, What makes chemistry difficult? African Journal of Chemical Education 4(2) (2014) 31-43. https://www.ajol.info/index.php/ajce/article/vie $\mathrm{w} / 104070$

[10] H. Sokrat, S. Tamani, M. Moutaabbid, \& M. Radid, Difficulties of students from the faculty of science with regard to understanding the concepts of chemical thermodynamics, Procedia - Social and Behavioral Sciences 116 (2014) 368-372.

DOI: https://doi.org/10.1016/j.sbspro.2014.01.223

[11] R. K. Coll, S. Ali , J. Bonato, D. Rohindra, Investigating first-year chemistry learning difficulties in the South Pacific: A case study from Fiji, International Journal of Science and Mathematics Education 4 (2005) 365-390. DOI: https://doi.org/10.1007/s10763-005-9007-6

[12] B. Ferrell, M. M. Phillips, \& J. Barbera, Connecting achievement motivation to performance in general chemistry, Chem. Educ. Res. Pract. 17(4) (2016) 1054-1066. DOI: https://doi.org/10.1039/C6RP00148C

[13] Suyatno, Wantini, Baidi, G. Amurdawati, The influence of values and achievement motivation on teacher professionalism at Muhammadiyah 2 high school Yogyakarta, Indonesia, Pedagogy
133(1) (2019) 105-127. DOI: https://doi.org/10.15823/p.2019.133.6

[14] J. M. Keller, \& T. W. Kopp, An application of the ARCS model of motivational design Instructional Theories in Action ed $\mathrm{C} \mathrm{M}$ Reigeluth, Lawrence Erlbaum Associates. pp 289-320, 1987.

[15] Y. Liu, J. R. Raker, \& J. E. Lewis, Evaluating student motivation in organic chemistry courses: moving from a lecture-based to a flipped approach with peer-led team learning, Chem. Educ. Res. Pract. 19 (2018) 251-264. DOI: https://doi.org/10.1039/C7RP00153C

[16] A. Augustinovič, Educational opportunities of natural science motivation for students with special educational needs: The viewpoint of natural science teachers, Pedagogy 136 (2019) 141-152.

DOI: https://doi.org/10.15823/p.2019.136.9

[17] N. R. Dyrberg, A. H. Treusch, C. Wiegand, Virtual laboratories in science education: Students' motivation and experiences in two tertiary biology courses, Journal of Biological Education $51 \quad$ (2016) 1-17. DOI: https://doi.org/10.1080/00219266.2016.1257498

[18] E. E. Olakanmi, A. I. Gambari, E. B. Gbodi, N. E. Abalaka, Promoting intrinsic and extrinsic motivation, Int J Edu Sci 12 (2016) 155-168.

[19] K. Vaino, J. Holbrook \& M. Rannikmae, Stimulating students' intrinsic motivation for learning chemistry through the use of contextbased learning modules, Chemistry Education Research and Practice. 13 (2012) 410-419. DOI: https://doi.org/10.1039/c2rp20045g

[20] A. S. Onen, \& F. M. Ulusoy, Developing the context-based chemistry motivation skill: validity and reliability analysis, Journal of Baltic Science Education 3(6) (2014) 809- 820.

[21] M. Stuckey, \& I. Eilks, Increasing student motivation and the perception of chemistry's relevance in the classroom by learning about tattooing from a chemical and societal view, Chem. Educ. Res. Pract. 15 (2014) 156-167. DOI: https://doi.org/10.1039/C3RP00146F

[22] I. B. Yuliastini, S. Rahayu, F. Fajaroh, \& N. Mansour, Effectiveness of POGIL with SSI context on vocational high school students' chemistry learning motivation, Jurnal Pendidikan IPA Indonesia, 7(1) (2018) 85-95, DOI: https://doi.org/10.15294/jpii.v7i1.9928

[23] A. Cetin-Dindar, \& O. Geban, Conceptual understanding of acids and bases concepts and 
motivation to learn chemistry, The Journal of Educational Research 110(1) (2017) 1-13. DOI: https://doi.org/10.1080/00220671.2015.1039422

[24] A. Tarkin, \& E. Uzuntiryaki-Kondakci, Implementation of case-based instruction on electrochemistry at the $11^{\text {th }}$ grade level, Chem. Educ. Res. Pract. 18(4) (2017) 659-681. DOI: https://doi.org/10.1039/C7RP00062F

[25] A. Çam, \& O. Geban, Effectiveness of casebased learning instruction on pre-service teachers' chemistry motivation and attitudes toward chemistry, Research in Science \& Technological Education 35(1) (2017) 74-87. DOI:

https://doi.org/10.1080/02635143.2016.1248927

[26] L. B. Wheeler, J. L. Chiu, J. L. Maeng, R. L. Bell, An exploratory study of teaching assistants' motivation for inquiry-based teaching in an undergraduate laboratory context, Chem. Educ. Res. Pract. 20(1) (2019) 53-67. DOI: https://doi.org/10.1039/C8RP00157J

[27] O. T. Kırık, \& Y. Boz, Cooperative learning instruction for conceptual change in the concepts of chemical kinetics, Chem. Educ. Res. Pract. 13(3), (2012) 221-236. DOI: https://doi.org/10.1039/C1RP90072B

[28] S. S. Sumarti, S. R. S. Aris, \& R. N. Aini, Chemo entrepreneurship with cooperative integrated process inquiry strategy to increase students' entrepreneurial interest and learning motivation, Jurnal Pendidikan IPA Indonesia $7(2) \quad$ (2018) 172-180. DOI: https://doi.org/10.15294/jpii.v7i2.12206

[29] L. Partanen, How student-centred teaching in quantum chemistry affects students' experiences of learning and motivation - a selfdetermination theory perspective, Chem. Educ. Res. Pract. 21 (2020) 79-94. DOI: https://doi.org/10.1039/C9RP00036D

[30] H. Gresch, M. Hasselhorn, \& S. Bögeholz, Enhancing decision-making in STSE education by inducing reflection and self-regulated learning, Res. in Sci. Educ. 47 (2017) 95-118. DOI: https://doi.org/10.1007/s11165-015-9491$\underline{9}$

[31] K. Chanapimuk, S. Sawangmek, \& P. Nangngam, Using science, technology, society, and environment (STSE) approach to improve the scientific literacy of grade 11 students in plant growth and development, Journal of Science Learning 2 (2018) 14-20. DOI: https://doi.org/10.17509/js1.v2i1.11997
[32] N. Yoruk, I. Morgil, \& N. Secken, The effects of science, technology, society, environment (SETS) interactions on teaching chemistry, Natural Science Journal 2(12) (2010) 14171424.

[33] S. Gathong, \& S. Chamrat, The implementstion of science, technology, and society environemnt (STSE) based learning for developing preservice general science teachers' understnading of the nature of science by empirical evidence, Jurnal Pendidikan IPA Indonesia 8 (2019) 354360.

DOI: https://doi.org/10.15294/ipii.v8i3.19442

[34] M. Rohmadi, Peran multimedia interaktif dalam pembelajaran, Proceeding Education and Language International Conference 6 (2011) 1737.

[35] Kaendler, C., Wiedmann, M., Rummel, N., \& Spada, H. (2015). Teacher competencies for the implementation of collaborative learning in the classroom: A framework and research review. Educational Psychology Review, 27(3), 505536.

[36] J. W. Creswell, Research design: Qualitative, quantitative, and mixed methods approaches, SAGE Publications, Inc, 2014.

[37] J. R. Fraenkel, N. E. Wallen, \& H. H. Hyun, How to design and evaluate research in education (8th ed.) McGraw-Hill. pp 90-109, 2012.

[38] M. Vitrianingsih, Unpublished bachelor thesis FMIPA UNY, 2006.

[39] J. P. Guilford, \& B. Fruchter, Fundamental statistics in psychology and education (6th edition), McGraw-Hill, Inc. p 356, 1938.

[40] J. A. Gliem, \& R. R. Gliem, Proc. of Midwest Research to Practice Conference in Adult, Continuing, and Community Education (Colombus) vol 1, The Ohio State University $\mathrm{p}$ 87, 2003.

[41] A. C. Austin, N. B. Hammond, N. Barrows, D. L. Gould, \& I. R. Gould, Relating motivation and student outcomes in general organic chemistry, Chem. Educ. Res. Pract. 19(1) (2018) 331-341.

DOI: https://doi.org/10.1039/C7RP00182G

[42] V. F. Savec, \& I. Devetak, Evaluating the effectiveness of students' active learning in chemistry, Procedia-Social and Behavioral Sciences 106 (2013) 1113-1121. 
[43] A. Wiyarsi, H. Pratomo, \& E. Priyambodo, Vocational high school students' chemical literacy on context-based learning: a case of petroleum topic Journal of Turkish Science Education 17(1) (2020) 147-161. DOI: http://dx.doi.org/10.36681/tused.2020.18.

[44] N. Fitriyana, A. Wiyarsi, J. Ikhsan, \& K. H. Sugiyarto, Andoroid-based-game and belended learning in chemistry: Effect on students' selfefficacy and achievement, Cakrawala Pendidikan 39(3) (2020) 507-521. DOI: https://doi.org/10.21831/cp.v39i3.28335

[45] L. Vinko, S. Delaney, \& I. Devetak, Teachers' opinion about the effect of chemistry demonstrations on students' interest and chemistry knowledge, CEPS Journal 10 (2020) 9-25. DOI: https://doi.org/10.26529/cepsj.893

[46] N. Fitriyana, A. Wiyarsi, J. Ikhsan, \& K. H. Sugiyarto, Fostering of students' self-regulated learning and achievement: A study on hydrocarbon hybrid-learning and chemondrogame, J. Phys.: Conf. Ser. 1097 (2018) 012064. DOI: $\quad$ http://dx.doi.org/10.1088/1742$\underline{6596 / 1097 / 1 / 012064}$

[47] A. Wiyarsi, N. Fitriyana, \& J. Ikhsan, Using technology in hydrocarbon topics: A profile on students' self-regulated learning, Journal for the Education of Gifted Young Scientists 7(4) (2019) 961-972. DOI: http://dx.doi.org/10.17478/jegys.2018.82

[48] K. Broman, \& D. Johnels, Flipping the class university chemistry students' experiences from a new teaching and learning approach, Chemistry Teacher International 20180004 (2019) 1-8. DOI: https://doi.org/10.1515/cti2018-0004 